\author{
RESEARCHPAPER
}

\title{
Incidence of resistance plasmid in thermotolerant bacterial indicators isolated from various sites of Ganges and Yamuna rivers, Allahabad, U.P.
}

\author{
AVANTIKA PANDEY AND O.P. VERMA \\ Department of Molecular and Cellular Engineering, Sam Higginbottom Institute of Agriculture, Technology and \\ Sciences, ALLAHABAD (U.P.) INDIA \\ Email : avantika.alld1@gmail
}

Article Info :Received : 08.12.2015; Accepted : 09.02.2016

In this study the thermotolerant bacterial indicators E.coli and Klebsiella were isolated from the water samples of rivers Ganges and Yamuna from various sampling stations. Antibiotic susceptibility revealed the MDR among most of the thermotolerant bacterial species. In case of metal tolerance the thermotolerant species were found to be highly tolerant towards most of the metals tested. The curing pattern for the resistance traits were tested and found that the curing effect was observed in thermotolerant species. The resistant traits were found to be plasmid borne and were able to transfer their resistance to the sensitive ones. Presence of plasmid DNA was also observed in resistant strains of thermotolerant species which were found to be cured. The plasmids were of small to medium size. All the strains possess only one plasmid. The study demonstrates that the resistance to antibiotic and metal ions were found to be generally associated with transmissible R-plasmid.

Key words : Thermotolerant, Resistant plasmid, DNA, Transfer of resistance

How to cite this paper : Pandey, Avantika and Verma, O.P. (2016). Incidence of resistance plasmid in thermotolerant bacterial indicators isolated from various sites of Ganges and Yamuna rivers, Allahabad, U.P. Asian J. Bio. Sci., 11 (1) : 85-90 [Special Issue of AFBSAH-2016]. 